\title{
Analysis of PEST and SWOT in Photovoltaic Power Generation Project in Poverty Alleviation Region
}

\author{
Jiahui Zhang \\ School of Economics and Management, North China \\ Electric Power University \\ Beijing China \\ Min Sun \\ State Grid Jiangxi Electric Power Company Electric Power \\ Research Institute
}

\author{
Wei Zeng \\ State Grid Jiangxi Electric Power Company Electric Power \\ Research Institute \\ Cunbin Li \\ School of Economics and Management, North China \\ Electric Power University \\ Beijing China
}

\begin{abstract}
Poverty alleviation projects are the focus of the country in recent years, in order to ensure that the $P V$ poverty alleviation project can achieve satisfactory results, the project needs in the internal and external environment in-depth analysis. In this paper, the SWOT-PEST method was used to analyze the factors influencing the photovoltaic power generation projects in poverty alleviation areas. Based on the analysis of each element in SWOT-PEST matrix, the qualitative analysis of each element was carried out by using analytic hierarchy process (AHP). It is concluded that the economic disadvantage is the most important to other factors. In the process of project implementation, more attention to this element. For the first time, the SWOT-PEST matrix analysis method is applied to the $P V$ poverty alleviation project, and the most important elements are found in the obtained elements, and the expected conclusions are obtained.
\end{abstract}

Keywords-PV; SWOT-PEST; analytic hierarchy process

\section{INTRODUCTION}

The sun is the root of all things to survive, is the catalyst for photosynthesis of plants, and the solar energy has inexhaustible advantages. In 2011, the share of carbon dioxide emissions in the country reached $45.4 \%$, and the emission intensity of carbon dioxide per unit of electricity was as high as 764 kilograms per megawatt more than the developed countries and the global average [1]. In addition, photovoltaic power generation can solve the energy crisis, in many developed countries in the world have been effectively applied. Jiangxi is a famous revolutionary base, with rich historical and cultural heritage, is located in southern China, adequate light for photovoltaic power generation has a unique advantage. Distributed photovoltaic power generation and networking can not only alleviate the energy crisis is conducive to protecting the environment, but also can make the installation of distributed power generation residents get considerable income, increase the economic source. In this paper, SWOT-PEST matrix analysis is used to analyze the external and external environment of photovoltaic power generation project, which lays the foundation for the safe and effective operation of the project.

Supported projects: State Grid Corporation project funding "to improve the photovoltaic poverty alleviation areas of power consumption capacity and security technology research and application"(52182017000W).

\section{SWOT AND PEST ANALYSIS OF PHOTOVOLTAIC POWER GENERATION PROJECT SWOT AND PEST ANALYSIS OF PHOTOVOLTAIC POWER GENERATION PROJECT}

\section{A. SWOT Analysis}

Under normal circumstances SWOT analysis of the use of the object is the enterprise, but the same applies to the analysis of the project. SWOT analysis method is an objective and scientific evaluation of the external environment and internal conditions of the object being analyzed. Where $\mathrm{S}$ and $\mathrm{W}$ represent internal strengths and weaknesses, respectively, $\mathrm{O}$ and $\mathrm{T}$ represent external opportunities and threats.

\section{B. PEST Analysis}

PEST is composed of the first word of politics, economy, society, and technology. PEST is mainly on the macroenvironment analysis, in view of the macro environmental factors are numerous, and in order to facilitate the analysis is divided into four categories. Through the analysis of these four factors, from the macro to grasp the external environment in which the project is conducive to timely detection of their own strengths and weaknesses, to avoid disadvantages, so that the project can be more effectively implemented.

\section{SWOT-PEST Analysis Paradigm}

The SWOT-PEST paradigm is an effective way to identify opportunities and threats from the political, economic, social and technical aspects of the advantages and disadvantages of the environment and the environment. Will be listed in the matrix of each element, so you can use their own advantages to seize the opportunity advantage, while grasping the opportunity to overcome their own inferior disadvantage opportunities, the use of their own advantages to deal with the threat of threat, and use the threat to overcome their own disadvantages threat [2]. 
TABLE I. SWOT-PEST MATRIX MODEL

\begin{tabular}{|l|c|c|c|c|}
\hline $\begin{array}{c}\text { SWOT-PEST } \\
\text { analysis }\end{array}$ & $\begin{array}{c}\text { Political } \\
(\mathrm{P})\end{array}$ & $\begin{array}{c}\text { Economic } \\
(\mathrm{E})\end{array}$ & Society (S) & Technology (T) \\
\hline Strengths (S) & SP & SE & SS & ST \\
\hline Weaknesses (W) & WP & WE & WS & WT \\
\hline Opportunity (O) & OP & OE & OS & OT \\
\hline Threatening (T) & TP & TE & TS & TT \\
\hline
\end{tabular}

\section{ANALYSIS OF PROJECT ADVANTAGES}

\section{A. Political Strengths}

In 2014, the State Council issued the "Energy Development Strategy Action Plan (2014-2020)", pointing out that the next six years is an important strategic opportunity for China's energy development and transformation, and the new energy power system represented by photovoltaic power generation is supported by national policy. In March 2016, the National Development and Reform Commission and other five departments jointly issued a "on the implementation of photovoltaic power generation poverty alleviation work", the full deployment of the implementation of photovoltaic poverty alleviation projects. In October 2016, the National Energy Board, the State Council Poverty Alleviation Office jointly issued the 'issued on the first batch of photovoltaic poverty alleviation project notice', the total scale of photovoltaic poverty alleviation project reached $5.16 \mathrm{GW}$. Among them, the village level photovoltaic power plant (including household) a total of $2.18 \mathrm{GW}$, centralized ground power station total 2.98GW. Jiangxi Province on the work of poverty alleviation work in the province pointed out that all levels of government to actively cooperate with the photovoltaic poverty alleviation work, included in the planned poverty alleviation project priority to enjoy the subsidy. Provincial departments are also very supportive of the PV project, will try to meet the implementation of photovoltaic poverty alleviation work conditions.

\section{B. Economic Strengths}

With the rapid economic development, the increasing consumption of electricity in the community, distributed photovoltaic power generation can be used for their own day, the surplus electricity can be connected, so that not only can effectively relieve power grid pressure, but also save electricity and bring A certain income. 2016 Jiangxi Province, the total regional output value of RMB18364.41 billion, and increasing $9 \%$ over the previous year, the rapid economic development in Jiangxi Province can not do without the PV poverty alleviation project made contributions, 2013, Jiangxi PV industry revenue reached RMB80.95 billion, in recent years it is still continuing to grow. On the other hand, the province's economic strength growth can promote the implementation of photovoltaic projects, economic strength will be able to increase the amount of money to buy the necessary equipment, put more human and material resources, so the cycle can get more returns. Therefore, the economic growth and the implementation of PV poverty alleviation projects are mutually reinforcing and mutually reinforcing.

\section{Social Strengths}

Jiangxi Province is located in the southeast, east of Zhejiang Province, Fujian Province, south of Guangdong Province, west of Hunan Province, north of Hubei Province, Anhui Province and common with the Yangtze River, is an important part of the Yangtze River Economic Zone. The province covers an area of 16.69 million square kilometers, belonging to the subtropical climate, hot summer heat, the annual average temperature of about $16.3-19.5^{\circ} \mathrm{C}$, and winter short summer long, for the photovoltaic power generation has sufficient light. Jiangxi Province is a large province of photovoltaic power generation, whether it is the development of photovoltaic products or personnel training are walking in the forefront of the industry. The province so much for the characteristics of solar photovoltaic colleges and universities, such as Nanchang University Solar Photovoltaic Academy, Xinyu College, these colleges and universities continue to the community to transport solar photovoltaic talent. In addition, Jiangxi Province is rich in mineral resources, especially for the manufacture of solar photovoltaic cells, quartz, reserves of nearly 20 million tons of the first in the country. Rock salt reserves of more than 10 billion tons, fluorite close to 10 million tons. These rich mineral resources guarantee the number of raw materials in the photovoltaic industry and the quality is stable.

\section{Technical Strengths}

Photovoltaic power generation has been really started since 1954 , the world's photovoltaic industry development are highly valued, after more than half a century of development of photovoltaic power generation technology has been very mature, more and more widely used. At present, polysilicon has replaced monocrystalline silicon as the main photovoltaic material, reducing the use of silicon materials can effectively reduce the cost, so the film into a crystalline silicon solar cell development direction, the current efficiency has reached $10 \%$, and low energy consumption, process Simple, low cost [3]. China's photovoltaic technology is entering the ranks of the world's advanced level, from 2007 to 2014, China's photovoltaic power generation costs down more than ten times, Hannon Group acquired the United States Global Solar Energy company, and has mastered the copper indium gallium selenium, Amorphous silicon - germanium, amorphous silicon - nano silicon and other seven leading global film technology line. In addition, many colleges and universities in Jiangxi 
Province have set up a PV-related professional, they cultivate a large number of photovoltaic talent, and photovoltaic technology in their painstaking research will be more and more advanced.

\section{DISADVANTAGES ANALYSIS}

\section{A. Political Weaknesses}

PV industry in China is still a new industry, in our country's existing system, the government if you want to support the development of an industry is not a difficult thing, so in the initial stage of the photovoltaic industry is still sailing. But with the continuous development of political resistance will become increasingly prominent. Solar power can not be completely consumed on the spot, and we also need this clean energy instead of traditional energy, so photovoltaic power generation must be incorporated into the grid. National Development and Reform Commission has been to encourage photovoltaic power generation, but the national grid is not necessarily able to accept a higher photovoltaic prices, the views of the two departments is generally not easy to coordinate, which will hinder the development of photovoltaic projects. Second, the current large-scale power generation enterprises are mainly five major state-owned enterprises, although the recent reform has been, but this reform is not overnight, relative to the distributed photovoltaic power generation, the national grid is certainly more willing and state-owned five power generation group.

\section{B. Economic Weaknesses}

The cost of photovoltaic power generation in developing countries is between $\$ 0.2$ and $\$ 0.35$ per kilowatt-hour [4], which is much more costly than traditional energy sources. In order to encourage its development, the electricity price is 1.15 per kilowatt-hour in 2011; in 2016 the government in order to encourage technological innovation, per kilowatt-hour electricity price down to 0.9 yuan, which undoubtedly makes the installation of distributed photovoltaic power generation households to reduce a certain amount of income. And the cost of installing photovoltaic power generation equipment is high, one-time investment is very large, but its investment payback period is very long, if you can not guarantee a stable income, this investment has a very big risk.

\section{Social Weaknesses}

Solar energy is relatively low, so photovoltaic power generation needs to occupy a large area, because the installation of photovoltaic power generation equipment area is limited, so the photovoltaic power generation is limited. Photovoltaic power generation is also affected by the intensity of solar radiation, its output has a strong random and intermittent, and then on the grid peak shunt, FM, standby, power flow, bus voltage and so have a greater impact [5]. The quality of photovoltaic power generation is also affected by the climate is very large, if there is no sun weather, then the power generation will be extremely small. Power generation system only in a well-lit place, the application state to achieve the desired results. Poverty alleviation areas are mostly remote mountainous areas, the maintenance and repair of equipment also has some difficulties.

\section{Technical Weaknesses}

In the poverty-stricken areas to develop photovoltaic industry, the purpose is to surf the Internet through photovoltaic power to get online profits. Distributed photovoltaic power generation access to the grid can be low, medium and high voltage, which is the most widely used low voltage. However, distributed photovoltaic access distribution network will change the traditional distribution network of radiation type distribution, distribution network voltage management problem is the development of large-scale distributed photovoltaic power generation one of the biggest challenges [6]. Moreover, the conversion efficiency of solar cells is relatively low, resulting in lower power generation system, which is a bottleneck in photovoltaic power generation, these problems are in urgent need of further solution.

\section{PROJECT OPPORTUNITY ANALYSIS}

\section{A. Political Opportunity}

Global warming has been threatening the survival of mankind, for which the "Paris Climate Agreement" has also begun the formal implementation of various countries, environmental protection programs are constantly improving. The government's first rectification industry is energy, from the traditional energy to the transition of clean energy is full of opportunities, the Government also vigorously support all kinds of clean energy projects. The Fifth Plenary Session of the Eighth Central Committee proposed to maintain the rapid growth of the economy, people's living standards and quality significantly improved to achieve poverty alleviation of the poor, poor counties to pick the hat. According to the Outline of China's Rural Poverty Alleviation and Development (20112020), the Decision of the CPC Central Committee and the State Council on Winning the Battle of Poverty and the Outline of the 13th Five-Year Plan for National Economic and Social Development of the People's Republic of China, Three five "during the establishment of photovoltaic power generation target guidance mechanism; increase financial support; supporting power grid construction and operation mechanism; the establishment of photovoltaic power generation market for the price management policy.

\section{B. Economic Opportunities}

The initial investment in photovoltaic power generation is the most important cost, and its operation during the maintenance, maintenance, etc. is only a very small part. In the continuous innovation and innovation of photovoltaic technology, the initial investment in distributed photovoltaic equipment is getting lower and lower, which shows that in the future distributed photovoltaic power generation will bring more and more profits to the residents. Moreover, the larger the internal rate of return, the shorter the static investment payback period and the better the project economy [7].

\section{Social Opportunities}

Jiangxi Province, geographical location, adjacent to a number of provinces, most of these provinces are more developed provinces, the industrial area will be more natural electricity consumption. If the distributed photovoltaic power 
generation in Jiangxi Province into the grid, if the province can not be completely consumed can be considered to transport these excess energy to the province. If this approach is feasible to reduce the occurrence of abandoned light events, while the installation of distributed power plant residents can get more revenue, our poverty alleviation goals can be further realized.

\section{Technical Opportunities}

China since 1985 has been on the photovoltaic technology research, in the early 80s also introduced the United States of new technology, after decades of research in China's photovoltaic technology has been in a leading position. In the world, photovoltaic technology has been rapid development in the electricity market, the proportion of photovoltaic power generation is growing, in the distributed photovoltaic, the United States, Germany and other core technology, in the technical standards, power construction and other aspects are significant Effectiveness. In addition, the voltage instability of the photovoltaic power generation system can be installed by the battery energy storage device, in the photovoltaic power generation period storage of excess energy, can inhibit the voltage fluctuations. In the night or rainy weather will be stored power release, and played a role in suppressing voltage fluctuations and continuous power supply [8].

\section{PROJECT THREAT ANALYSIS}

\section{A. Political Threats}

In the poverty-stricken areas, the purpose of implementing photovoltaic power generation is to hope that the residents of poverty-stricken areas can get some income from the grid through photovoltaic power generation, which naturally will not cooperate with the national network. In China's political system, the State Grid as a state-owned enterprises have the right to choose power generation enterprises, in the relevant policy support distributed photovoltaic power generation can naturally access the grid. If one day the country canceled these preferential policies, the State Grid should not be so that these costs are higher than the thermal power of photovoltaic power generation successfully access the grid. In addition, if the photovoltaic power generation instead of the traditional thermal power, then the coal industry and thermal power plants will face layoffs, about 18 million people or $15 \%$ of the national labor force [9].

\section{B. Economic Threats}

Because of the high cost of photovoltaic power generation equipment, pre-investment is very large, if the government wants to rely on photovoltaic projects to win this fight out of poverty need to invest more money, but in recent years, China's economy from high growth to medium-speed growth Period, into the new economic state, the state financial funds in the photovoltaic infrastructure, new technology development, subsidies and other aspects of electricity prices may appear powerless situation. Moreover, after entering the new economic normal, the development of industry is also worse than before, which means that industrial electricity may not increase rapidly, then the phenomenon will appear abandoned light, which is bound to bring losses to the residents.

\section{Social Threats}

Photovoltaic power generation projects as a clean and pollution-free large-scale power generation projects, photovoltaic projects to ease the pressure on supply and demand in China to improve the level of energy conservation and emission reduction role, the market demand is large, but because of the technical, price and production capacity than conventional energy There is a certain gap, the market competitiveness is relatively poor [10]. Solar energy itself is a clean energy, in order to take advantage of this energy photovoltaic equipment used in the various parts of the raw materials in a series of processing also use a lot of energy, but also cause environmental pollution. Due to the particularity of photovoltaic power generation equipment, its operation and maintenance process will have some carbon dioxide emissions [11]. Moreover, clean energy is not only photovoltaic, as well as wind, nuclear, etc., if the country also vigorously support other clean energy, will cause great competition.

\section{Technical Threats}

Photovoltaic industry as a sunrise industry, for the distributed photovoltaic access grid research is still relatively small. With the increase of photovoltaic power generation capacity, the stochastic and intermittent contribution to the system can not be neglected [12]. And domestic and foreign research on large-scale distributed photovoltaic power generation technology does not fully consider the characteristics of poverty alleviation areas, these features will bring some technical problems. 


\section{MATRIX MODEL ANALYSIS}

According to the matrix model of Table 1, the model analysis matrix is obtained by combining all of the above analysis.

TABLE II. SWOT-PEST MATRIX MODEL ANALYSIS

\begin{tabular}{|c|c|c|c|c|}
\hline $\begin{array}{c}\text { SWOT-PEST } \\
\text { analysis }\end{array}$ & $\begin{array}{l}\text { Political factors } \\
\text { (P) }\end{array}$ & $\begin{array}{l}\text { economic factors } \\
\text { (E) }\end{array}$ & social factors $(\mathbf{S})$ & $\begin{array}{c}\text { Technical factors } \\
\text { (T) }\end{array}$ \\
\hline Strength (S) & $\begin{array}{l}\text { (1) New energy } \\
\text { power system to } \\
\text { obtain national } \\
\text { support. } \\
\text { (2) The relevant state } \\
\text { departments support } \\
\text { the PV poverty } \\
\text { alleviation project. } \\
\text { (3) Jiangxi } \\
\text { provincial } \\
\text { government actively } \\
\text { cooperate with the } \\
\text { photovoltaic work. }\end{array}$ & $\begin{array}{l}\text { (1) PV projects bring } \\
\text { benefits to poverty } \\
\text { alleviation areas. } \\
\text { (2) Jiangxi Province, } \\
\text { sustained economic } \\
\text { growth is conducive to } \\
\text { the implementation of } \\
\text { the project. } \\
\text { (3) PV projects can } \\
\text { drive economic growth. }\end{array}$ & $\begin{array}{l}\text { (1) Jiangxi Province, } \\
\text { geographical location, } \\
\text { and more provinces } \\
\text { adjacent. } \\
\text { (2) More talent. } \\
\text { (3) Rich mineral } \\
\text { resources. }\end{array}$ & $\begin{array}{l}\text { (1) From the global } \\
\text { perspective, } \\
\text { photovoltaic } \\
\text { technology has been } \\
\text { relatively mature. } \\
\text { (2)Domestic } \\
\text { photovoltaic } \\
\text { technology in the } \\
\text { continuous progress, } \\
\text { master a number of } \\
\text { core technologies. }\end{array}$ \\
\hline Weakness (W) & $\begin{array}{l}\text { (1) Due to the } \\
\text { national institutional } \\
\text { problems, there is an } \\
\text { obstacle to } \\
\text { photovoltaic power } \\
\text { generation. }\end{array}$ & $\begin{array}{l}\text { (1) High cost of } \\
\text { photovoltaic power } \\
\text { generation. } \\
\text { (2) Tariff subsidies } \\
\text { down. }\end{array}$ & $\begin{array}{l}\text { (1) Photovoltaic } \\
\text { equipment accounted } \\
\text { for a large area. } \\
\text { (2) Power generation } \\
\text { effect is impacted by } \\
\text { the weather and } \\
\text { climate. } \\
\text { (3) Poor transportation } \\
\text { in poor areas, } \\
\text { equipment maintenance } \\
\text { and repair equipment } \\
\text { have difficult. }\end{array}$ & $\begin{array}{l}\text { (1) The management } \\
\text { problem of } \\
\text { photovoltaic power } \\
\text { generation } \\
\text { distribution network } \\
\text { voltage is difficult to } \\
\text { solve. }\end{array}$ \\
\hline $\begin{array}{l}\text { Opportunity } \\
\text { (O) }\end{array}$ & $\begin{array}{l}\text { (1) The world is } \\
\text { implementing } \\
\text { environmental } \\
\text { programs, the } \\
\text { government supports } \\
\text { clean energy projects. } \\
\text { (2) The national } \\
\text { "thirteen five" plan } \\
\text { includes the PV } \\
\text { poverty the } \\
\text { alleviation project. }\end{array}$ & $\begin{array}{l}\text { (1) With the reduction } \\
\text { of technological } \\
\text { development costs, the } \\
\text { profitability of PV } \\
\text { growth is large. } \\
\text { (2) Improve their own } \\
\text { use ratio, better } \\
\text { economic benefits. }\end{array}$ & $\begin{array}{l}\text { (1) With the industrial } \\
\text { province from the near, } \\
\text { the excess power can } \\
\text { be output. }\end{array}$ & $\begin{array}{l}\text { (1) Photovoltaic } \\
\text { technology is } \\
\text { becoming more and } \\
\text { more common. (2) } \\
\text { You can install the } \\
\text { battery, make up for } \\
\text { the shortcomings of } \\
\text { photovoltaic power } \\
\text { generation. }\end{array}$ \\
\hline $\begin{array}{l}\text { Threatening } \\
\text { (T) }\end{array}$ & $\begin{array}{l}\text { (1) The power of the } \\
\text { grid company is very } \\
\text { large. } \\
\text { (2) PV instead of } \\
\text { thermal power, power } \\
\text { plants will be a lot of } \\
\text { layoffs, undermine } \\
\text { social stability. }\end{array}$ & $\begin{array}{l}\text { (1) The state into the } \\
\text { new economic normal, } \\
\text { slow economic growth, } \\
\text { inhibit the development } \\
\text { of photovoltaic } \\
\text { projects. }\end{array}$ & $\begin{array}{l}\text { (1) Market } \\
\text { competitiveness is } \\
\text { poor. } \\
\text { (2) Raw material } \\
\text { development process } \\
\text { energy consumption, } \\
\text { causing pollution to the } \\
\text { environment.(3) } \\
\text { Compete with other } \\
\text { clean energy. }\end{array}$ & $\begin{array}{l}\text { (1) Support for large- } \\
\text { scale distributed PV } \\
\text { access to the grid is } \\
\text { not skilled.(2) At } \\
\text { home and abroad to } \\
\text { study the } \\
\text { photovoltaic power } \\
\text { generation access to } \\
\text { the grid did not fully } \\
\text { consider the } \\
\text { characteristics of } \\
\text { poverty alleviation } \\
\text { areas. }\end{array}$ \\
\hline
\end{tabular}




\section{APPLICATION OF ANALYTIC HIERARCHY PROCESS IN SWOT-PEST ANALYSIS}

\section{A. Introduction to analytic hierarchy process}

In the mid-1970s, the United States Satti formally proposed analytic hierarchy process. He points out that analytic hierarchy process (AHP) is an analytical method which is systematic and hierarchical to the research object. It has the characteristics of qualitative analysis and quantitative analysis [13]. There are four methods of weighting commonly used in analytic hierarchy process: geometric mean method, arithmetic mean method, eigenvector method and least squares method.

\section{B. Establish a hierarchical model}

In the application of AHP analysis, first we must divide the factors in the problem into several levels. The number of layers is related to the complexity of the problem. The more detailed the problem is, the more detailed the number of layers needs to be divided. These levels are generally divided into three categories: the target layer, the standard layer, the program layer. SWOT-PEST analysis of the advantages, disadvantages, opportunities, threats for the standard layer, is the same level of four levels. Politics, economy, society and technology for the program layer.

\section{Constructing judgment matrix}

According to the above SWOT-PEST paradigm analysis, based on the expert scoring method, the elements of SWOT are compared in pairs, and then the four elements in SWOT analysis are compared in each group. In order to ensure the consistency of the judgment matrix, we need to check the consistency of the matrix, in which the consistency index CI.

$$
\mathrm{CI}=\left(\lambda_{\max }-\mathrm{m}\right) /(\mathrm{m}-1)
$$

Where $\lambda_{\max }$ is the largest eigenvalue of the matrix and the $\mathrm{m}$ is the order of the matrix. The smaller the value of $\mathrm{CI}$, the higher the degree of consistency of the matrix. In order to test whether the matrices of different orders are satisfactory, it is necessary to introduce the average random consistency index RI. The value of RI is obtained by looking up the table. Also calculate the random consistency ratio $\mathrm{CR}$

$$
\mathrm{CR}=\mathrm{CI} / \mathrm{RI}
$$

When $\mathrm{CR}<0.1$, the judgment matrix is considered to be satisfactory, otherwise it is necessary to adjust the judgment matrix until it has satisfactory consistency [14].

After the matrix conforms to the consistency check, the hierarchical single order weight of each element is calculated. First of all, the sum of the columns of the judgment matrix is obtained, and then the summation result is normalized to obtain the weight coefficients of each index. According to the above steps to draw the following table.
TABLE III. PHOTOVOLTAIC POWER GENERATION PROJECT SWOT ANALYSIS JUDGMENT MATRIX Z

\begin{tabular}{lllll}
\hline $\mathbf{Z}$ & $\mathbf{P}$ & $\mathbf{E}$ & $\mathbf{S}$ & $\mathbf{T}$ \\
\hline $\mathrm{P}$ & 1 & $1 / 3$ & $1 / 3$ & $1 / 3$ \\
\hline $\mathrm{E}$ & 3 & 1 & $1 / 2$ & 3 \\
\hline $\mathrm{S}$ & 3 & 2 & 1 & 2 \\
\hline $\mathrm{T}$ & 3 & $1 / 3$ & $1 / 2$ & 1 \\
\hline
\end{tabular}

TABLE IV. ADVANTAGE JUDGMENT MATRIX S

\begin{tabular}{lllll}
\hline S & SP & SE & SS & ST \\
\hline SP & 1 & $1 / 3$ & $1 / 3$ & $1 / 3$ \\
\hline SE & 3 & 1 & $1 / 2$ & 3 \\
\hline SS & 3 & 2 & 1 & 2 \\
\hline ST & 3 & $1 / 3$ & $1 / 2$ & 1 \\
\hline
\end{tabular}

TABLE V. DISADVANTAGES JUDGMENT MATRIX W

\begin{tabular}{lllll}
\hline W & WP & WE & WS & WT \\
\hline WP & 1 & $1 / 3$ & 2 & $1 / 2$ \\
\hline WE & 3 & 1 & 5 & 3 \\
\hline WS & $1 / 2$ & $1 / 5$ & 1 & $1 / 2$ \\
\hline WT & 2 & $1 / 3$ & 2 & 1 \\
\hline
\end{tabular}

TABLE VI. OPPORTUNITY JUDGMENT MATRIX

\begin{tabular}{lllll}
\hline O & OP & OE & OS & OT \\
\hline OP & 1 & $1 / 4$ & $1 / 7$ & $1 / 5$ \\
\hline OE & 4 & 1 & $1 / 2$ & 2 \\
\hline OS & 7 & 2 & 1 & 3 \\
\hline OT & 5 & $1 / 2$ & $1 / 3$ & 1 \\
\hline
\end{tabular}

TABLE VII. ThreAt JudGMENT MATRIX

\begin{tabular}{lllll}
\hline $\mathbf{T}$ & $\mathbf{T P}$ & $\mathbf{T E}$ & $\mathbf{T S}$ & $\mathbf{T T}$ \\
\hline $\mathrm{TP}$ & 1 & $1 / 3$ & $1 / 4$ & 3 \\
\hline $\mathrm{TE}$ & 3 & 1 & $1 / 3$ & 2 \\
\hline $\mathrm{TS}$ & 4 & 3 & 1 & 6 \\
\hline $\mathrm{TT}$ & $1 / 3$ & $1 / 2$ & $1 / 6$ & 1 \\
\hline
\end{tabular}

TABLE VIII. LEVEL SINGLE SORT AND CONSISTENCY CHECK

\begin{tabular}{llllll} 
& S & W & O & T & CR \\
\hline $\mathrm{Z}$ & 0.262 & 0.483 & 0.1005 & 0.155 & 0.0650 \\
\hline $\mathrm{P}$ & 0.104 & 0.156 & 0.059 & 0.122 & \\
\hline $\mathrm{E}$ & 0.284 & 0.541 & 0.269 & 0.201 & \\
\hline $\mathrm{S}$ & 0.447 & 0.101 & 0.510 & 0.582 & \\
\hline $\mathrm{T}$ & 0.165 & 0.202 & 0.162 & 0.085 & \\
\hline $\mathrm{CR}$ & 0.090 & 0.024 & 0.036 & 0.08 & \\
\hline
\end{tabular}

As can be seen from Table 8, each judgment matrix has passed a consistency check. ThE overall ranking is based on Table 8, and the results arE SHOWN IN Table 9. 
TABLE IX. TOTAL RANKING OF THE HIERARCHY

\begin{tabular}{|c|c|c|c|c|c|}
\hline \multicolumn{2}{|c|}{$\mathbf{S}$} & W & O & $\mathbf{T}$ & CR \\
\hline $\mathrm{P}$ & 0.027 & 0.075 & 0.006 & 0.019 & \multirow{4}{*}{0.051} \\
\hline $\mathrm{E}$ & 0.075 & 0.261 & 0.027 & 0.033 & \\
\hline $\mathrm{S}$ & 0.117 & 0.049 & 0.051 & 0.090 & \\
\hline $\mathrm{T}$ & 0.043 & 0.096 & 0.016 & 0.013 & \\
\hline
\end{tabular}

\section{CONCLUSION}

By using the organic combination of SWOT-PEST paradigm analysis and analytic hierarchy process, many factors influencing the photovoltaic power generation project can be quantitatively analyzed. It can be concluded from Table 9 that the overall ranking of the hierarchy also passes the one-off test, and that WE is the greatest of the economic disadvantage in all the factors, and it can be seen that the economic disadvantage is the most important for the photovoltaic project. Poverty alleviation areas of their own economy is not developed, and photovoltaic projects need a lot of investment funds, so the state and local governments to actively find the source of funds to increase investment efforts.

Using SWOT-PEST paradigm analysis can not only draw the situation of the environment in which the project is located, but also can analyze from different angles and get more objective and realistic results. Using the analytic hierarchy process to qualitatively analyze the elements in the paradigm, sort the elements according to the results obtained, and pay more attention to the important elements in the project implementation, so as to ensure the project can achieve the desired results.

\section{REFERENCES}

[1] International Energy Agency. IEA CO2 emissions from fuel combustion: highlights(2013 edition)[R].Paris,France:IEA,2013.

[2] Gonghao Cui, Xingping Wang. Introduction to Contemporary Regional Planning [M]. Nanjing: Southeast University Press, 2006.

[3] Baofu Wu, Xiangyan Wang. The characteristics and development of solar photovoltaic power generation technology [J]. Power and Energy, 2011 (01): 74-79.

[4] Schmidt T S, Born R, Schneider M. Assessing the costs of photovoltaic and wind power in six developing countries[J].Nature Climate Change, 2012 (2):548-553

[5] Xi Zhang, Chongqing Kang, ect. Chinese and long-term stochastic characteristics of solar photovoltaic power generation [J]. Automation of Electric Power Systems, 2014,38 (6): 6-13.

[6] Caihao Liang, Xianzhong Duan. Distributed power generation and its influence on power system [J]. Automation of Electric Power Systems, 2001, 25 (12): 53-56.

[7] Yashi Chao, Qionghui LI. Economic Analysis and Development Prediction of Photovoltaic Power Generation Technology [J]. China Electric Power, 2012 (08): 64-68.

[8] iaoyan $\mathrm{Xu}$, Yuehui Huang, Chun Li, ect. Effects of Distributed Photovoltaic Power Generation on Distribution Network Voltage and Voltage Limiting Solution [J]. Power System Technology, 2010 (10): 140-146.

[9] Yian Yin. Study on the Political Obstruction of Photovoltaic Power Generation in China [D]. Nanjing: Nanjing University, 2016.

[10] Yanbin Li, Xinyi Wang, Zhijie Wang. Remote Sensitivity and TOPSIS Method for Risk Assessment of Photovoltaic Power Generation Project [J]. Power System Technology, 2013 (06): 1514-1519.

[11] Fengzhang Luo, Zhaofeng Mi, Chengshan Wang, ect. Characteristics of low carbon comprehensive benefit analysis for grid-connected photovoltaic power generation project $[\mathrm{J}]$. Automation of Electric Power Systems, 2014 (38): 163-169.

[12] Xiuli Wang, Zechen Wu, Chong Qu. Journal of Chinese Society of Electrical Engineering, 2014 (01): 15-21.

[13] Huijuan Zhao. Research on Enterprise Intelligent Strategy Decision Method Based on SWOT Analysis [D]. Beijing: Beijing Jiaotong University, 2007.

[14] Yongxiu He, etc. Electricity comprehensive evaluation method and application [M]. Beijing: China Electric Power Pres s, 2011. 